$24 \mathrm{c}$

7. Сапелин А.Ю. Живые згороди / А.Ю. Сапелин. - М. : Изд-во "Кладезь Букс", 2008.

8. Полозун Л.Г. Озеленение и декоративное оформление жилой настройки / Л.Г. Полозун, М.Л. Мысак и др. - М. : Изд-во АСТ; Донецк : Изд-во "Сталкер", 2005. - 159 с.

Надійшла до редакиії 24.05.2016 p.

Мирончук K.В. Особенности пространственной структуры типичных живых изгородей и их классификация

Описаны типичные живые изгороди, что являются распространенным элементом современного озеленения в урбанизированной среде. Рассмотрены особенности пространственной структуры формированных и неформированных типовых живых изгородей. Приведена расширенная классификация типичных живых изгородей по ряду характеристик пространственной структуры живых изгородей, которые используются в озеленении населенных мест. Охарактеризованы основные классификационные структурные единицы типичных формированных и неформованных живых изгородей - форма ухода, видовой состав, тип, высота, рядность, фронтальная форма и поперенное сечение живых изгородей. Внделена типичная живая нзгородь, как конструктивня едииица сложной живой изгороди.

Ключевые слова: формированная и неформированная живая изгородь, пространственная структура живой изгороди, тип, рядность, фронтальная форма и поперечное сечение живых изгородей

Myronchuk K.V. Some Peculiarities of the Spatial Structure of Common

\section{Hedges and their Classification}

Some typical hedges that are common parts of modern gardening in the urban environment are described. The peculiarities of spatial structure of shaped and unshaped common types of hedges are considered. The extended classification of typical hedges by a number of characteristics of spatial structure of hedges which are used in landscaping of urbanized areas is given. The main classification of structural elements of shaped and unshaped typical hedges is described. They are the following: the method of care, species composition, type, height, row number, frontal shape and a cross section. A typical hedge as a constructive unit complex of hedges is highlighted.

Keywords: typical hedge, spatial structure of hedge, type, row number, the front shape and a cross section of hedges.

\section{УДК 630*231}

\section{ПРИРОДНЕ ЛІСОВІДНОВЛЕННЯ У ПРОГАЛИНАХ БУКОВИХ ЛІСІВ ПРИРОДНОГО ЗАПОВІДНИКА "РОЗТОЧЧЯ"}

\section{О.Б. Михайлів ${ }^{1}$, Г.В. Стрямець ${ }^{2}$, І.Г. Хомин}

Наведено результати дослідження природного лісовідновлення у прогалинах старовікових букових лісів природного заповідника "Розточчя". Обстежено вісім прогалин розміром від 236 до 3927 м² в однорідному типі лісу - вологій грабовій бучині. Виявлено, що найкраще процес природного поновлення бука лісового відбувався на прогалинах IV категорії віку. Найбільшу кількість життездатного підросту спостережено у вікнах розміром приблизно 800-1000 м². Крім Fagus sylvatica L., на прогалинах добре відновлюються Acer pseudoplatanus L., Quercus robur L., Carpinus betulus L., piдше - Acer platanoides L., Ulmus glabra Huds.

ст. викл. О.Б. Михайлів, канд. с.-г. наук - НЛТУ України, м. Львів;

заст. дир. $з$ наук. робот, ст. наук. співроб. Г.В Стрямець, канд. с.-г. наук - ПЗ "Розточчя", Львівська обл.; наук. співроб. І.Г. Хомин - ПЗ "Розточчя", Львівська обл.
Ключові слова: старовікові ліси, "вікна", вік прогалин, бурелом, сухостій.

Одним із завдань заповідників є вивчення природних процесів і явищ, які відбуваються в екосистемах. Природний заповідник "Розточчя" утворено у 1984 р., понад 92\% його території покрито лісом, 3 них ліси віком більше 100 років займають площу близько 33 \%, тому дослідження природних процесів розпаду деревостанів і їх природне відновлення є актуальним. Букові ліси на Розточчі $€$, поза сумнівом, природного походження, вони цікаві для дослідників у зв'язку з вивченням сукцесій, пов'язаних зі специфічними особливостями бука, який як едифікатор, що володіє вираженою експансивною активністю, формує потужне фітогенне поле. Букові угруповання відносять до клімаксових, у них практично не здатний впровадитися жоден алохтонний вид [1, 3, 4]

Мета та завдання роботи - оцінити стан природного лісовідновлення у прогалинах (вікнах), утворених унаслідок буреломів та вітровалів у букових лісах у природному заповіднику "Розточчя".

Об'єкт дослідження - різні за розміром "вікна" у стиглих та перестійних деревостанах природного заповідника "Розточчя", які виявили в трьох кварталах з однорідним типом лісу - вологою грабовою бучиною. Відібрано "вікна", що утворилися внаслідок відпаду з різних причин 3-7 дерев.

Предмет дослідження - процес природного лісовідновлення на прогалинах, які утворилися природним шляхом під час вітровалів і буреломів.

Методи та методика дослідження. Плошу "вікон" розраховано як поверхню, не заняту проекціями крон дерев, шо прилягають до прогалини.

Одночасно встановлювали орієнтовний вік прогалини за ступенем розкладу повалених дерев, користуючись п'ятиступеневою класифікацією, яку згадано в працях J. Szewczyk і J. Szwagrzyk (1996 р.). Ступінь розкладу присвоювали за такими критеріями:

- дерева 3 неушкодженою корою, деревина тверда, наявні гілки крони дерев;

II - дерева 3 частково ушкодженою корою, деревина тверда з ознаками загнивання лубу, мохи покривають $10-15$ \% кори, наявні гілки крони дерева;

III - дерева з відшарованою корою або вкритою мохами чи іншою рослинністю на 25-75 \% поверхні, деревина м'яка з ознаками загнивання, наявні лише скелетні гілки крони;

IV - стовбури без кори покриті рослинністю на 75-100 \%, деревина дуже м'яка, гілки відсутні, але стовбури надалі утримують циліндричну форму;

$\mathrm{V}$ - стовбури повністю вкриті мохами чи рослинністю, здеформовані [5].

У межах прогалин для обліку підросту закладали 5 кругових облікових ділянок радіусом 1,75 м. Одну облікову ділянку розміщували по центру, а чотири - по контуру прогалини відносно сторін світу (північ, південь, захід, схід) на відстані 5 м від проекції крон материнського деревостану. Облік підросту, а далі і оцінювання успішності природного поновлення здійснено за методикою М.М. Горшеніна (1971р.).

Результати дослідження. Бук лісовий на території заповідника є однією 3 головних лісотворних порід, росте у свіжих і вологих гігротопах у суборевих, сугрудових та грудових трофотопах. Більше 15 \% площі заповідника займають букові ліси віком понад 100 років, які зосереджені головним чином у Вере- 
щицькому ПОНДВ. Дослідження природного поновлення у лісах заповідника свідчать про те, що бук, як тіньовитривала автохтонна порода, успішно відновлюється в усіх сприятливих типах лісорослинних умов під деревним наметом, лише у "вікнах" переважає явір, який з часом частково витісняється буком [1, 4]. Протягом 2014-2015 рр. проведено дослідження прогалин букових лісів, які утворилися внаслідок вітровалів і буреломів, опис наведено нижче.

ПП-1 Верещицьке ПОНДВ, кв. 4, вид. 10. Прогалина витягнутої форми 3 північного сходу на південний захід довжиною близько 100 м, площа

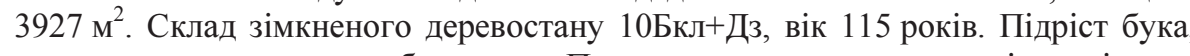
клена гостролистого, граба, явора. Прогалина утворилася внаслідок відпаду 7 дерев бука: 5 вітровальних буків - кора тримається на стовбурах, на 2 деревах тримається сухе листя, 1 дерево - у кроні мертві гілки, стовбур затягнуло ожиною, 2 буреломні стовбури бука - 1 бурелом зі живою кроною, 1 - бурелом сухостою. Прогалина свіжа, дерева I ступеня розкладу. Утворювалась упродовж 2 років - 2014 і 2015. Розширення прогалини триває.

ПП-2 Верещицьке ПОНДВ, кв. 4, вид. 10. Віддалена від попередньої на 150 м на схід. Довжина прогалини 3 південного сходу на північний захід -

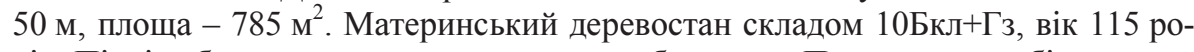
ків. Підріст бука, клена гостролистого, граба, явора. Прогалина комбінована за походженням внаслідок відпаду 7 дерев бука: 4 вітровальних буків - 2 свіжі вітровали, 2 стовбури на стадії розкладу, вкриті мохом, 2 буреломні стовбури бука - 1 бурелом $з$ живою кроною, 1 - бурелом сухостою.

Прогалина свіжа, дерева II ступеня розкладу, утворена впродовж 2014 p.

ПП-3 Верещицьке ПОНДВ, кв. 4, вид. 10. Віддалена від попередньої приблизно 400 м на схід. Рельєф - пологий, мікросхил північно-східної експо-

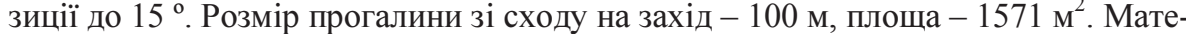
ринський деревостан 10Бкл+Гз, вік - 115 років, повнота - 0,7. Підріст бука, клена гостролистого, граба, явора. Прогалина комбінована внаслідок відпаду 5 дерев бука: 3 вітровальні буки в поточному 2015 р. зі живою кроною, 2 буреломні стовбури бука старого сухостою.

ПП-4 Верещицьке ПОНДВ, кв. 15, вид. 1. Довжина прогалини зі сходу

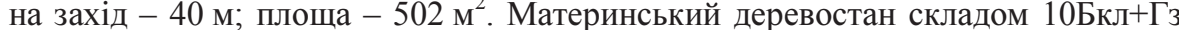
вік 120 років. Підріст бука, клена гостролистого, граба, явора. Прогалина комбінована внаслідок відпаду 3 дерев бука: 2 буреломних буки в 2014 р., кора міцно тримається стовбура, крона добре розгалужена без листя, 1 буреломний стовбур бука старого сухостою. Прогалина утворена орієнтовно в 2014 р. Буреломні дерева І ступеня розкладу.

ПП-5 Верешицьке ПОНДВ, кв. 15, вид. 1. Рельєф - пологий схил південно-західної експозиції. Довжина прогалини з південного заходу на північ-

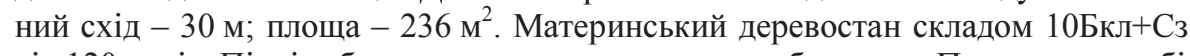
вік 120 років. Підріст бука, клена гостролистого, граба, явора. Прогалина комбінована внаслідок відпаду 4 дерев бука: 3 буреломних дерева у 2013-2014 pp. кора міцно тримається стовбура, крона добре розгалужена без листя, 1 буреломний стовбур бука старого сухостою. Центр прогалини не захаращений, дерева II ступеня розкладу.
ПП-6 Верещицьке ПОНДВ, кв. 8, вид. 5. Рельєф - горбистий, схил північної експозиції. Протяжність прогалини з півночі на південь - 45 м; площа -

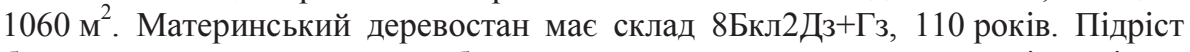
бука, клена гостролистого, граба, явора. Прогалина утворилася внаслідок відпаду 5 дерев: 3 вітровальних буків, 1 граба та 1 клена гостролистого. Крона повалених дерев жива - кора тримається на стовбурах. Прогалина свіжа зі стовбурами I ступеня розкладу, утворилася у 2015 p.

ПП-7 Верещицьке ПОНДВ, кв. 8, вид. 5. Розмір прогалини з півночі на південь - 30 м; площа - 635,9 м². Материнський деревостан 8Бкл2Дз $+Г 3$, 110 років. Підріст бука, клена гостролистого, граба, явора. Прогалина утворилася внаслідок відпаду 7 дерев. Старий бурелом, стовбури на V стадії розкладу. Прогалина давня, добре освітлена.

ПП-8 Верещицьке ПОНДВ, кв. 8, вид. 5. Рельєф - горбистий, схил південно-західний. Довжина прогалини зі заходу на схід -55 м, плоша -1036 м $^{2}$

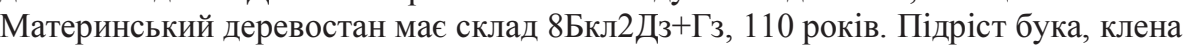
гостролистого, граба, явора. Прогалина утворилася внаслідок відпаду 5 дерев. Буреломні стовбури граба і бука перебувають на IV стадії розкладу, прогалина давня, відзначається сильним задернінням грунту. у таблиці.

Результати обліку підросту на пробних площах у переводі на 1 га подано

Табл. Оцінка успішності природного поновлення у прогалинах

\begin{tabular}{|c|c|c|c|c|c|c|c|c|c|}
\hline \multirow{3}{*}{$\begin{array}{l}\text { № } \\
\text { 프 П }\end{array}$} & \multirow{3}{*}{ Вік* } & \multirow{3}{*}{$\begin{array}{c}\text { ЖНП, } \\
\%\end{array}$} & \multirow{3}{*}{$\begin{array}{c}\text { Поро- } \\
\text { да }\end{array}$} & \multicolumn{5}{|c|}{ К Кількість підросту, 1 тис. шт./га } & \multirow{3}{*}{$\begin{array}{c}\text { Оцінка успішності } \\
\text { природного } \\
\text { поновлення }\end{array}$} \\
\hline & & & & \multicolumn{4}{|c|}{ Вік, років } & \multirow{2}{*}{ Разом } & \\
\hline & & & & 1 & $2-3$ & $4-7$ & $>7$ & & \\
\hline \multirow{4}{*}{1} & \multirow{4}{*}{ I } & \multirow{4}{*}{35} & Бкл & 0,20 & 0,40 & 2,60 & 3,40 & 7,97 & добре \\
\hline & & & $\Gamma 3$ & 0 & 0,40 & 0,20 & 1,20 & 2,24 & недостатне \\
\hline & & & Яв & 0 & 0,80 & 0,80 & 3,00 & 5,78 & задовільне \\
\hline & & & Разом & 0,20 & 1,60 & 3,60 & 8,00 & 16,59 & - \\
\hline \multirow{5}{*}{2} & \multirow{5}{*}{ II } & \multirow{5}{*}{65} & Бкл & 0,40 & 3,60 & 1,80 & 4,20 & 10,32 & добре \\
\hline & & & $\Gamma 3$ & 0 & 0 & 1,00 & 1,00 & 2,50 & недостатне \\
\hline & & & Яв & 0 & 1,00 & 1,40 & 1,20 & 3,80 & задовільне \\
\hline & & & Клг & 0 & 0 & 1,20 & 0,20 & 1,50 & - \\
\hline & & & Разом & 0,40 & 4,60 & 5,60 & 6,60 & 18,32 & $\begin{array}{llll}- & & & \\
-\end{array}$ \\
\hline \multirow{5}{*}{3} & \multirow{5}{*}{ II } & \multirow{5}{*}{75} & Бкл & 0 & 0,80 & 0,60 & 2,80 & 5,28 & задовільне \\
\hline & & & $\Gamma 3$ & 0 & 0 & 0,20 & 0,80 & 1,40 & недостатне \\
\hline & & & Яв & 0 & 0,20 & 1,40 & 2,20 & 4,82 & задовільне \\
\hline & & & Клг & 0 & 0 & 0,20 & 0,20 & 0,50 & - \\
\hline & & & Разом & 0 & 1,00 & 2,40 & 6,00 & 12,00 & - \\
\hline \multirow{5}{*}{4} & \multirow{5}{*}{ I } & \multirow{5}{*}{5} & Бкл & 0,20 & 0,40 & 0,80 & 0,80 & 2,27 & недостатне \\
\hline & & & $\Gamma 3$ & 0 & 1,20 & 0 & 1,00 & 2,22 & недостатне \\
\hline & & & Яв & 0 & 0,60 & 0 & 2,40 & 3,96 & задовільне \\
\hline & & & Клг & 0 & 0 & 0 & 0,60 & 0,90 & $\begin{array}{llll}- & & & \\
\end{array}$ \\
\hline & & & Разом & 0,20 & 2,20 & 0,80 & 4,80 & 9,35 & - \\
\hline \multirow[t]{4}{*}{5} & \multirow[t]{4}{*}{ II } & \multirow[t]{4}{*}{40} & Бкл & 0 & 2,60 & 0,20 & 1,20 & 3,56 & задовільне \\
\hline & & & $\Gamma 3$ & 0,20 & 0,80 & 0 & 0 & 0,51 & незадовільне \\
\hline & & & Яв & 0 & 0,60 & 0,80 & 2,40 & 4,76 & задовільне \\
\hline & & & Клг & 0 & 0,40 & 0,20 & 1,40 & 2,54 & - \\
\hline
\end{tabular}

1. Лісове та садово-паркове господарство 


\begin{tabular}{|c|c|c|c|c|c|c|c|c|c|}
\hline & & & Разом & $\overline{0,20}$ & $\bar{~} 4,40$ & $\bar{~} 1,20$ & 5,40 & $\begin{array}{l}11,97 \\
\end{array}$ & - \\
\hline \multirow{5}{*}{6} & \multirow{5}{*}{ I } & \multirow{5}{*}{90} & Бкл & 4,00 & 5,00 & 9,20 & 2,20 & 16,10 & добре \\
\hline & & & $\Gamma 3$ & 0 & 4,20 & 0,80 & 0,60 & 4,22 & задовільне \\
\hline & & & Яв & 5,80 & 17,60 & 2,60 & 2,00 & 17,03 & добре \\
\hline & & & Клг & 0 & 0,40 & 0 & 0 & 0,24 & - \\
\hline & & & Разом & 9,8 & 27,20 & 12,60 & 4,80 & 37,59 & - \\
\hline \multirow{7}{*}{7} & \multirow{7}{*}{$\mathrm{V}$} & \multirow{7}{*}{100} & Бкл & 10,0 & 0 & 3,00 & 4,00 & 10,50 & добре \\
\hline & & & $\Gamma 3$ & 0 & 0 & 0 & 1,00 & 1,50 & недостатне \\
\hline & & & Д3 & 0 & 0 & 1,60 & 1,40 & 3,70 & задовільне \\
\hline & & & Яв & 0 & 0 & 1,00 & 2,00 & 4,00 & задовільне \\
\hline & & & Клг & 0 & 0 & 0 & 1,80 & 2,70 & - \\
\hline & & & Взш & 0 & 2,00 & 0,20 & 0 & 1,40 & - \\
\hline & & & Разом & 10,0 & 2,00 & 5,80 & 10,20 & 23,80 & - \\
\hline \multirow{4}{*}{8} & \multirow{4}{*}{ IV } & \multirow{4}{*}{100} & Бкл & 0 & 0 & 13,40 & 10,40 & 29,00 & добре \\
\hline & & & $\Gamma 3$ & 0 & 0 & 0 & 3,00 & 4,50 & задовільне \\
\hline & & & Д3 & 0 & 2,20 & 0 & 0 & 1,32 & недостатнє \\
\hline & & & Разом & 0 & 2,20 & 13,40 & 13,40 & 34,82 & - \\
\hline
\end{tabular}

*Вікові категорії прогалин приймаємо умовно за ступенем розкладу деревини.

Результати оцінювання природного поновлення свідчать про те, що букові ліси в умовах Розточчя здатні до самовідновлення, як під деревним наметом, так і в прогалинах. У видовому складі підросту на обстежуваних прогалинах виявлено Fagus sylvatica L., Acer pseudoplatanus L., Quercus robur L., Carpinus betulus L., Acer platanoides L., Ulmus glabra Huds. На більшості прогалин у природному поновленні домінантна роль належить буку лісовому. Кількість підросту лісотворної породи змінюється від 2 тис. шт/га і аж до 29 тис. шт/га. Лише в одному випадку (ПП-4) кращими показниками, ніж бук лісовий, відзначився підріст клена-явора.

Щоб встановити роль прогалин у відновленні деревостанів, ключовим моментом було знайти залежність між кількістю підросту бука і супутніх порід, що сформувався в межах прогалини та розмірами прогалини і часом утворення. Як уже згадували, вікову категорію прогалини визначали відповідно до ступеня розкладу повалених дерев. Результати дослідження кількості життєздатного підросту залежно від віку прогалин наведено на рис. 1.

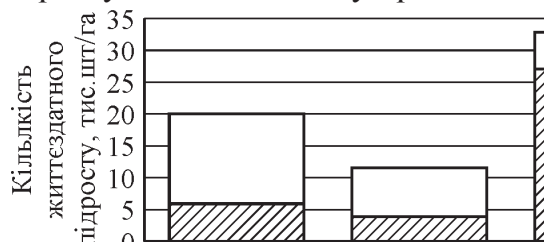

I

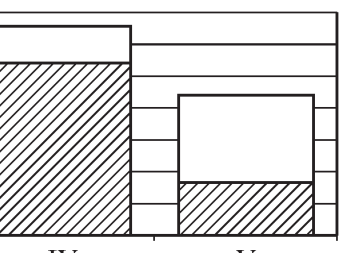

$\square$ Бук лісовий

$\square$ Супутні породи залежно від вікової категорії прогалини

3 діаграми видно, що найкраще процес природного поновлення бука лісового відбувався на прогалинах IV категорії віку. Маловтішним щодо відтворення деревостанів $\epsilon$ факт, що на старих прогалинах, віднесених до V категорії віку, збереглося найменше підросту бука лісового і переважає підріст супутніх порід. Проведені раніше дослідження свідчать, що під деревним наметом підріст бука $є$ конкурентоздатніший порівняно з іншими видами, тому є велика ймовірність, що згодом на прогалинах теж домінуватиме бук. Загалом, істотного зв'язку між кількістю життєздатного підросту бука та віком прогалин не виявлено. Під час аналізу впливу площі прогалин на кількість підросту бука лісового та супутніх порід (рис. 2) спостережено найбільшу кількість підросту на прогалині середнього розміру.

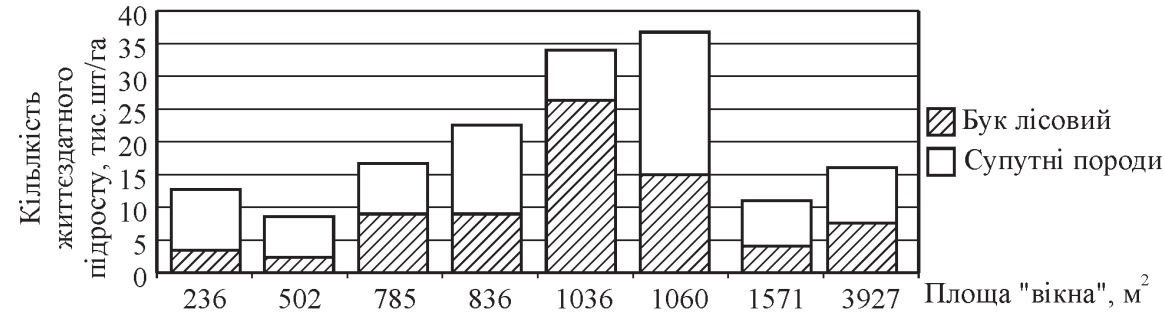

Рис. 2. Розподіл кількості життездатного підросту бука і супутніх порід залежно від розміру прогалин

Як видно з діаграми, прямий зв'язок між кількістю життєздатного підросту та розміром вікон відсутній, найбільшу кількість підросту виявлено у вікнах розміром приблизно 800-1000 м². На двох перших ділянках присутній нежиттєздатний підріст, його кількість не перевищує 2,4 тис. шт./га.

Висновки. У старовікових букових лісах природного заповідника "Розточчя" відбуваються природні процеси старіння та відмирання окремих дерев, які пошкоджуються буревіями і вітровалами. Під час обстеження кв. 4, 8, 15 Верещицького ПОНДВ, з однорідним типом лісу - вологою грабовою бучиною виявлено вісім прогалин розміром від 236 до 3927 м². Природне лісовідновлення у прогалинах відзначається високою життєздатністю, доброю та задовільною успішністю. Найкраще відновлення характерне для бука лісового, клена-явора.

Спостережено тенденцію, що на прогалинах малих і великих розмірів $\epsilon$ найменше підросту. Найбільша кількість підросту - на середніх за розміром прогалинах. Очевидно на малих прогалинах чинить притінення материнський деревостан, а на великих відкритих просторах спостережено захаращення великою кількістю стовбурів повалених дерев, а також розростання трав'яної рослинності, яка створює конкуренцію для підросту.

Встановлено, що найкраще процес природного поновлення бука лісового відбувався на прогалинах IV категорії віку.

\section{Література}

1. Бовт Я.С. Лісовідновлення в природному заповіднику "Розточчя" / Я.С. Бовт, Г.В. Стрямець, Н.М. Ференц // Дендрология, цветоводство и садово-парковое строительство : сб. науч. тр. - Ялта : Изд-во Никитского ботанического сада, 2012. - С. 11-12.

2. Горшенін М.М. Динаміка одноліток бука європейського на вирубках Карпат залежно від зімкнутості трав'яного покриву / М.М. Горшенін, Г.Т. Криницький, І.П. Савич // Підвищення продуктивності лісів та ефективності їх використання : зб. наук. праць. - Львів : Вид-во "Камепяр", 1973. - С. 6-10.

3. Дидух Я.П. Систематика и история развития бука в буковых лесах горного Крыма / Я.П. Дидух // Ботанический журнал : зб. наук. праць. - 1985. - Т. 70, № 8. - С. 1045-1048.

1. Лісове та садово-паркове господарство 
4. Стрямець Г.В. Давні букові ліси природного заповідника "Розточчя" / Г.В. Стрямець, Н.М. Ференц, Н.С. Стрямець // Науковий вісник НЛТУ України : зб. наук.-техн. праць. - Львів РВВ НЛТУ України. - 2015. - Вип. 25.1. - С. 96-101.

. Szewczyk J. Tree regeneration on rotten wood and on soil in old-growth stand. / J. Szewczyk, J. Szwagrzyk // Vegetatio. - 1996. - Issue. 122. - Pp. 37-46.

Надійшла до редакиії 18.04.2016 p.

Мыхайлив О.Б., Стрямеи Г.В., Хомын И.И. Естественное лесовосстановление в пробелах буковых лесов заповедника "Расточье"

Приведены результаты исследований естественного лесовосстановления в пробелах старовозрастных буковых лесов заповедника "Расточье". Обследовано восемь

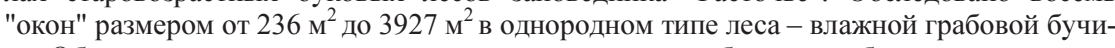
не. Обнаружено, что лучше процесс естественного возобновления бука лесного происходил на пробелах IV категории возраста. Наибольшее количество жизнеспособного подроста наблюдается в окнах размером примерно 800-1000 м². Кроме Fagus sylvati$c a \mathrm{~L}$, на пробелах хороно восстанавливаются Acer pseudoplatanus L., Quercus robur L. Carpinus betulus L., peже - Acer platanoides L., Ulmus glabra Huds.

Ключевые слова: старовековые леса, "окна", возраст пробелов, бурелом, сухостой.

Mychayliv O.B., Stryamets G.V., Khomin I.G. Natural Reforestation in the

\section{Beech Forest Gaps of the Natural Reserve "Roztochya"}

The results of studies of natural regeneration in old-growth beech forest gaps in the natural reserve "Roztochya" are presented. The study involved eight spaces ranging in size from $236 \mathrm{~m}^{2}$ to $3927 \mathrm{~m}^{2}$ in a homogeneous type of forests - wet hornbeam beech. The best proces of natural regeneration of beech forest gaps is found to take place in the IV age category. The reatest number of viable seedlings was observed in gaps mesuring about $800-1000 \mathrm{~m}^{2}$. Be-

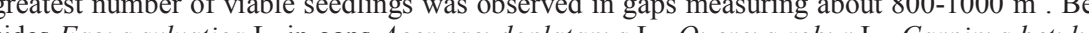
des Fagus sylvatica L. in gaps Acer pseudoplatanus L., Quercus robur L., Carpinus betulus L. were well restored, while Acer platanoides L., Ulmus glabra Huds were less restored.

Keywords: old-growth beech forests, gaps, gap age, windbreak, deadwood.

\section{УДК 630*182}

\section{ПОХІДНІ ДЕРЕВОСТАНИ ЛІСОСТЕПУ ХАРКІВЩИНИ}

\section{В.В. Назаренко}

Проаналізовано сучасний стан і продуктивність малоцінних та похідних деревостанів Лісостепу Харківщини. Закладено десять лісотипологічних профілів, де у найбільш характерних місцях зроблено описи ділянок лісу. Визначено загальну плошу похілних та корінних деревостанів, їх породнй склад Розраховано продуктивніс х ден зален зроблено відповідні висновки. Проаналізовано за складом корінні деревостани та виявлено невідповідність складу і структури таких насаджень оптимальним, що найбільш повно відповідають природним еталонам

Ключові слова: похідні деревостани, малоцінні деревостани, продуктивність, тип лісу, Лісостеп Харківщини.

Вступ. Проблеми, пов'язані зі збереженням та відтворенням лісів, а також 3 реалізацією принципів сталого ведення лісового господарства нагально постають як в Україні, так і у всіх країнах світу.

доц. В.В. Назаренко, канд. с.-г. наук. - Харківський НАУ ім. В.В. Докучаєва
Однією з важливих проблем, яку потрібно вирішити у найближчій перспективі, є ведення лісового господарства на засадах збалансованого розвитку. Згідно з міжнародними, погодженими між державами принципами, це передбачає такий рівень лісогосподарювання, за якого будуть отримувати максимальні екологічний, економічний та соціальний ефекти. В Україні відбуваються позитивні зміни у реалізації ідеї сталого лісокористування. Тому еколого-ресурсний потенціал лісів невпинно зростає, а загальний запас деревини за останні 50 років зріс більше ніж у 2 рази. Обсяги створення лісів за останні роки істотно перевищують площу щорічних суцільних зрубів. Використання у процесі лісокористування середнього приросту деревини не перевищує 50 \% [10].

Проте сучасний стан лісів України все ще недостатньо задовільний: використання лісами потенційної родючості грунтів рідко перевищує 70 \%. На певних площах відбувається негативна зміна порід і різке ослаблення деревостанів [10]. Ліси постійно перебувають під значним антропогенним впливом. Тому на чималих площах ростуть малоцінні й похідні деревостани, які сформувалися в умовах, порушених унаслідок діяльності людини або природних чинників і процесів. Похідними та малоцінними вважають деревостани, які сформувалися на місці корінних і $є$ результатом незадовільного відновлення чи невдало створених лісових культур за складом порід, запасом та якістю деревини [2].

Мета дослідження. Вивчення сучасного стану та продуктивності малоцінних та похідних деревостанів Лісостепу Харківщини.

Методика дослідження. Для дослідження типологічного різноманіття лісів використано "Методику лесотипологических исследований" Д.В. Воробйова [4]. До району досліджень увійшли такі державні лісогосподарські підприємства Харківської обл., ДП "Вовчанське ЛГ", ДП "Жовтневе ЛГ", ДП "Чугуєво-Бабчанське ЛГ", ДП "Зміївське ЛГ", Харківська ЛНДС УкрНДІЛГА та ДП "Скрипаївське НДЛГ", а також НПП "Гомільшанські ліси". 3 цією метою закладено 10 лісотипологічних профілів (по два у ДП "Скрипаївське НДЛГ" і ДП "Зміївське ЛГ" та по три у ДП "Чугуєво-Бабчанське ЛГ" і ДП "Вовчанське ЛГ"). Усі маршрути прокладено за схилом, перпендикулярно терасам. Профілі протяжністю від 4,5 до 14 км перетинають у різних частинах середньої течії Сiверського Дінця його заплаву, борову терасу та праві корінні береги.

У найбільш характерних місцях за ходом профілю зроблено детальні описи ділянок лісу, закладено пробні площі (табл. 1). Їх закладено з урахуванням вимог стандарту організацій України "Площі пробні лісовпорядні. Метод закладання" [9]. Розподіл насаджень за типами деревостанів виконано на основі "Шкали оцінки відповідності порід, що ростуть, типам лісу у межах лісорослинних зон України і припустимих відхилень залежно від категорії захисності лісів" [5]. Аналіз дослідних даних проведено з використанням прикладних комп'ютерних програм, а також геоінформаційних технологій. Розрахунки виконано на основі даних пробних площ та повидільної бази даних "Лісовий фонд".

Результати дослідження. Типологічне різноманіття лісів насаджень лісового фонду досить широке (табл. 2). Усього в районі досліджень виявлено 34 типи лісу, однак більше 94 \% території займають насадження, які ростуть в 5-ти типах лісу. За даними лісовпорядкування, найпоширенішим типом лісу $є$

1. Лісове та садово-паркове господарство 